\title{
A Case of Ectopic Tooth in the Maxillary Sinus Associated with a Mucocele
}

\author{
Tae Yong Kim, Byeong Jin Kim and Seong Kook Park \\ Department of Otorhinolaryngology-Head and Neck Surgery, Inje University School of Medicine, Busan Paik Hospital, Busan, Korea
}

\section{상악동 점액낭종과 동반된 이소치 1 예}

김태용 · 김병진 · 박성국

인제대학교 의과대학 부산백병원 이비인후-두경부외과학교실

\author{
Received April 18, 2012 \\ Revised July 2,2012 \\ Accepted July 2, 2012 \\ Address for correspondence \\ Seong Kook Park, MD, PhD \\ Department of Otorhinolaryngology- \\ Head and Neck Surgery, \\ Inje University School of Medicine, \\ Busan Paik Hospital, \\ 75 Bokji-ro, Busanjin-gu, \\ Busan 614-735, Korea \\ Tel $+82-51-890-6375,6379$ \\ Fax +82-51-892-3831 \\ E-mailssinus4@paik.ac.kr
}

Supernumerary, ectopic tooth eruption in a non-dental area is a rare entity. The ectopic development of tooth found in non-dental environment has been reported in places such as the nasal cavity, chin, maxillary sinus, mandibular bone, palate and orbital cavity. Ectopic tooth eruptions in the maxillary sinus are usually asymptomatic and are found incidentally during routine clinical or radiological investigations. The diagnosis is usually made by plain-film radiography. Computed tomography is indicated when an ectopic tooth is found prior to surgery. Standard treatment for an ectopic tooth is extraction of the tooth. Here, the authors present a case of supernumerary, ectopic tooth found in the maxillary sinus associated with a mucocele.

Korean J Otorhinolaryngol-Head Neck Surg 2012;55:527-9

\section{서 론}

과잉치(supernumerary teeth)는 정상 치아 이외에 발생하는 치아로 치아영역 외에서 발생하는 경우를 이소치(ectopic teeth) 라 한다. 치아영역 외에서의 과잉 이소치의 발현은 드문 편이나 ${ }^{1)}$ 정상위치가 아닌 비강내, 턱, 상악동, 하악골, 구개부, 안와부 등 에서 발견된다고 보고되고 있다. ${ }^{1,2)}$ 국내 문헌에서도 비강과 상 악동내에 발생한 이소치를 보고한 증례가 있으나 상악동 내측 에 점액낭종이 동반된 이소치는 보고된 바가 없다. ${ }^{3-6)}$ 이소치는 대부분 증상이 없고, 우연히 진찰이나 영상의학적 검사를 통해 우연히 발견되는 경우가 흔하며 ${ }^{7)}$ 상악동내의 이소치가 자연공 을 막아서 안면통, 비출혈, 농성비루, 두통 등의 증상이 나타난다. 치료원칙은 이소치의 적출이며 이소치의 위치에 따라 CaldwellLuc 접근법, 비강 내시경적 수술 등의 방법으로 적출할 수 있다. ${ }^{8,9}$

저자들은 국내에서 현재까지 보고된 바 없는 상악동 점액 낭종이 동반된 이소치 1 예를 성공적으로 치험하였기에 문헌고
찰과 함께 보고하는 바이다.

\section{증 례}

40세 남자 환자가 안면 비대칭을 주소로 3차 병원 성형외과 외래를 방문해서 시행한 안면 전산화단층촬영에서 우측 상악 동 골종 소견을 보여 본과에 의뢰되었다. 안면 비대칭 이외의 다 른 증상은 없었으며 과거 치과 검사상 이상소견이 없었고 가족 력 및 과거력, 외상, 수술에 대한 병력도 없었다. 이학적, 비내시 경 검사상 특이소견이 없었고 전산화단층촬영상 우측 상악동 에 골막으로 둘러싸인 $1.7 \times 3.3 \times 3.6 \mathrm{~cm}$ 크기의 균일한 연조직 음영 안에 $1 \times 1 \times 1.4 \mathrm{~cm}$ 정도의 석회화 음영이 우측 상악동 내 측벽에서 보였는데 석회화 음영의 중앙에 저음영 영역이 관찰 되었다(Fig. 1). 자연공 폐쇄 등 다른 이상소견은 관찰되지 않았 으며 그 외의 술전에 시행한 임상검사상 특별한 이상소견도 관 찰되지 않았다. 
수술은 전신 마취하에 시행하였으며, 전산화단층촬영상 mass 의 크기와 위치를 고려하였을 때 비강 내시경적 접근이 어려 울 것으로 판단되었고 상악동 자연공이 개창되어 있는 소견을 보여 이에 손상을 주지 않기 위하여 우측 상악동에 CaldwellLuc 접근법을 시행하였다.

비내시경하에 골겸자, 큐렛, 회전식 흡입기(microderbrider) 를 이용하여 점액낭종에 대하여 조대술(marsupialization)을 시행 후 상악동 내측벽에 있는 이소 치아를 확인하고 제거하였 다(Fig. 2). 이소 치아는 점액낭종 내에 있었으며 상악동의 내 측벽에 붙어 있는 양상이었다. 점액낭종은 점액으로 가득 차 있

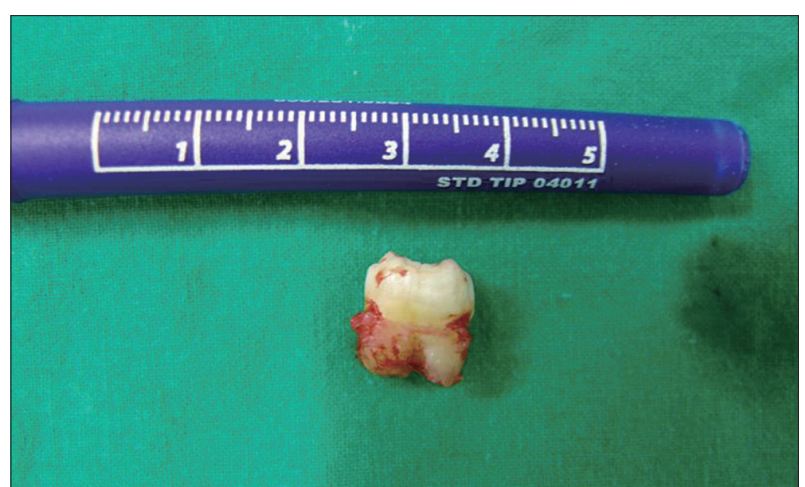

Fig. 2. View of the removed tooth. $1 \times 1.2 \times 0.8 \mathrm{~cm}$ sized molariform tooth with well developed roots.
었으며, 점도가 있고 탁한 양상의 전형적인 점액낭종의 분비물 양상이었다. 분비물은 따로 배양검사를 시행하지는 않았다. 제 거한 조직은 병리조직학적 검사상 전상아질 세관과 치아모세 포가 나란히 배열되어 있는 치아로 확인되었다(Fig. 3). 수술 후 항생제를 투여하였고 특별한 합병증 없이 술 후 2일째 퇴원하 였다. 수술 후 6 개월째 특별한 합병증 없이 추적관찰 중이다.

\section{고 찰}

이소치의 발생 원인은 정확히 밝혀진 것은 없으나, 영구치근 이 분리되거나 치근판의 국소적, 독립적인 기능의 증가로 발생 할 수 있다. ${ }^{10,11}$ 드물지만 다수로 발생하는 경우는 쇄골두개골 이형성증(cleidocranial dysplasia), 구순열과 구개열, Gardner 증후군과 같은 다른 질환과 동반되는 경우가 많다. ${ }^{12)}$ 따라서 유전적인 영향도 있는 것으로 생각된다. 본 증례와 같은 상악 동의 경우는 의인성, 외상성, 특발성일 수 있다. ${ }^{9)}$ 본 증례의 경우 는 상기한 병력 및 가족력은 없었다. 이소치로 인한 증상은 대 부분 없으나 비강내로 돌출되거나 부비동의 자연공을 막을 경 우 이물감, 비폐색, 악취, 농성비루, 두통, 안면통 등의 증상이 나 타날 수 있다. ${ }^{8)}$ 진단은 증상 및 이학적 검사가 도움을 줄 수는 있으나 영상의학적 검사로 상악동내 병변을 확인하는 것이 필
Fig. 1. Preoperative axial (A) and coronal (B) CT scans. Mucus containing, thin bony shell lesion $(1.7 \times$ $3.3 \times 3.6 \mathrm{~cm}$ ) within osteoma (black arrow) arising from medial wall ( $1 \times$ $1 \times 1.4 \mathrm{~cm}$ ) in right maxillary sinus.

Fig. 3. Developing tooth, sagittal section (H\&E stain, $\times 15)(A)$. Layer of polarized odontoblasts with Tome's fibers extending into tubules of predentin. After decalcification, Fibroblasts of pulp are loosely arranged (H\&E stain, $\times 100)(B)$.
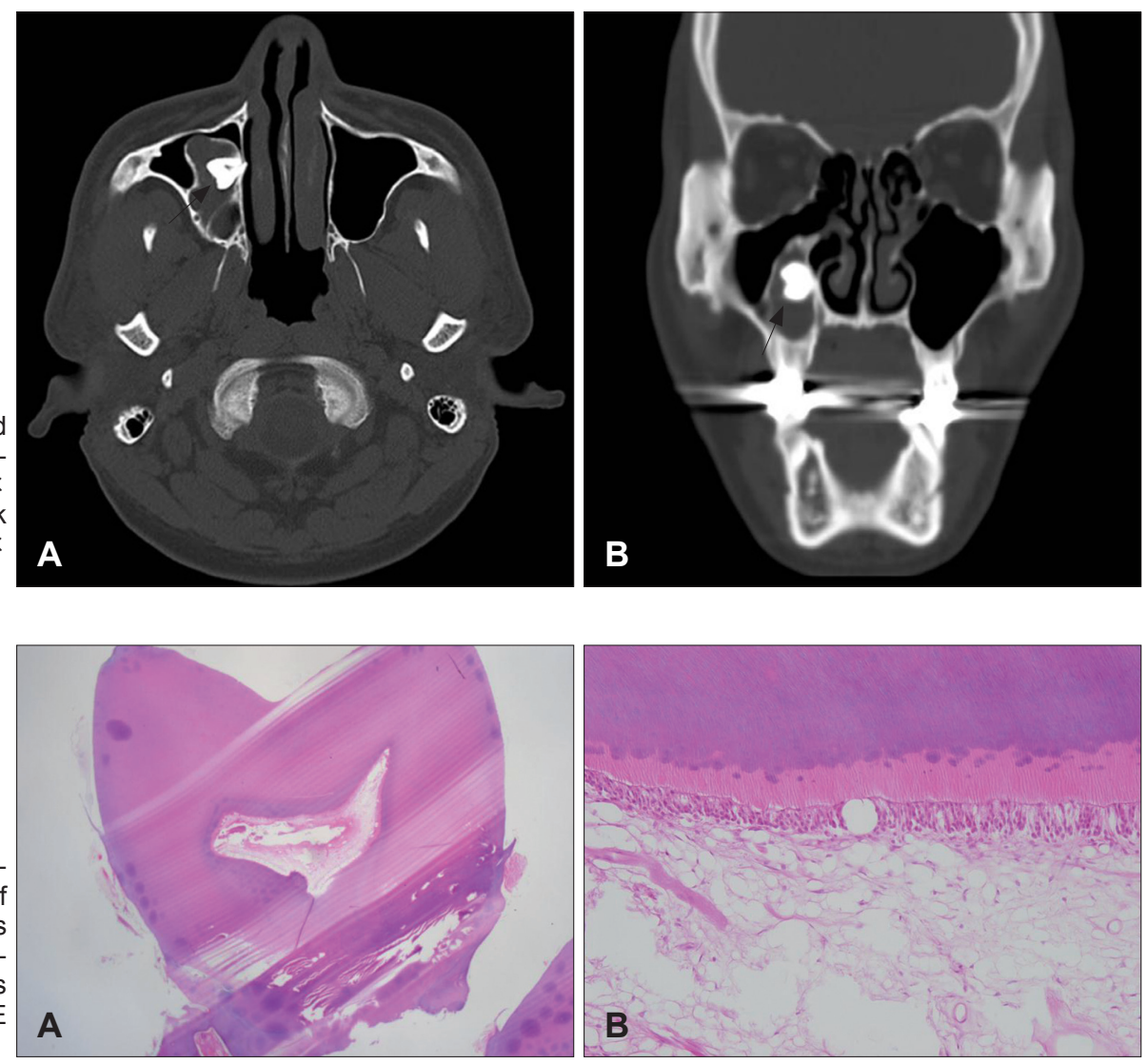
요하다. 단순방사선촬영으로 진단할 수 있으며 수술적 치료를 위해서는 전산화단층촬영이 필요하다. ${ }^{13)}$ 본 증례의 경우는 특 이증상 없이 미용적 성형수술을 목적으로 우연히 시행한 영상 의학적 검사로 발견되었다. 치료는 증상이 없다면 경과관찰 할 수 있으나 맹출된 이소치로 인하여 증상이 발생한다면 수술적 치료가 꼭 필요하다. ${ }^{8)}$ 치료원칙은 이소치의 적출이며 이소치의 위치에 따라 Caldwell-Luc 접근법 또는 비강 내시경 시술로 제 거한다. ${ }^{8)}$

본 증례의 경우 증상 없이 우연히 발견된 이소치라 꼭 제거 할 필요가 없다고 판단되었으나 향후 안면비대칭에 대한 성형 외과적 치료가능성과 점액낭종으로 인한 합병증 발생가능성도 있으며 환자가 원하여 수술을 시행하였다.

상악동 점액낭종이 동반된 이소치의 경우 외국에서 매우 드 물게 보고된 적은 있으나 국내에는 보고된 적이 없다. ${ }^{9)}$ 이에 저 자들은 국내에서 현재까지 보고된 바 없는 상악동 점액낭종 이 동반된 과잉 이소치 1 예를 성공적으로 치험하였기에 문헌 고찰과 함께 보고하는 바이다.

\section{REFERENCES}

1) Erkmen N, Olmez S, Onerci M. Supernumerary tooth in the maxillary sinus: case report. Aust Dent J 1998;43(6):385-6.

2) el-Sayed Y. Sinonasal teeth. J Otolaryngol 1995;24(3):180-3.

3) Shim YJ, Lee SS. Two cases of mesiodens in nasal cavity. Korean J Otolaryngol-Head Neck Surg 2007;50(12):1167-9.

4) Lee JH, Yun KJ. Supernumerary tooth in nasal cavity with septal perforation. Korean J Otolaryngol-Head Neck Surg 2002;45(2):187-90. 5) Lee WT, Park YK, Ahn KS, Kim SK. Three cases of the supernumerary teeth in the nasal cavity. Korean J Otolaryngol-Head Neck Surg 1981;24 (3):387-9.

6) Jung SY, Park EH, Bae JH, Lee SS. A cases of the supernumerary tooth within Fungus Ball in the maxillary sinus. Korean J OtolaryngolHead Neck Surg 2010;53(3):184-6.

7) Jude R, Horowitz J, Loree T. A case report. Ectopic molars that cause osteomeatal complex obstruction. J Am Dent Assoc 1995;126(12):1655-7. 8) Litvin M, Caprice D, Infranco L. Dentigerous cyst of the maxilla with impacted tooth displaced into orbital rim and floor. Ear Nose Throat J 2008; 87(3):160-2.

9) Lamb JF, Husein OF, Spiess AC. Ectopic molar in the maxillary sinus precipitating a mucocele: a case report and literature review. Ear Nose Throat J 2009;88(8):E6-11.

10) Liu JF. Characteristics of premaxillary supernumerary teeth: a survey of 112 cases. ASDC J Dent Child 1995;62(4):262-5.

11) Smith RA, Gordon NC, De Luchi SF. Intranasal Teeth. Report of two cases and review of the literature. Oral Surg Oral Med Oral Pathol 1979; 47(2):120-2.

12) Scheiner MA, Sampson WJ. Supernumerary teeth: a review of the literature and four case reports. Aust Dent J 1997;42(3):160-5.

13) Bodner L, Tovi F, Bar-Ziv J. Teeth in the maxillary sinus--imaging and management. J Laryngol Otol 1997;111(9):820-4. 